15. Cornelis, W. M., Ronsyn, J., van Meirvenne, M. and Hartmann, R., Evaluation of pedotransfer functions for predicting the soil moisture retention curve. Soil Sci. Soc. Am. J., 2001, 65, 638-648.

16. Kaur, R., Kumar, S., Gurung, R. P., Rawat, J. S., Singh, A. K., Prasad, S. and Rawat, G., Evaluation of pedotransfer functions for predicting field capacity and wilting point moisture content from routinely surveyed soil texture and organic carbon data. J. Indian Soc. Soil Sci., 2002, 50, 205-208.

17. Patil, N. et al., Soil water retention characteristics of black soils of India and pedotransfer functions using different approaches. J. Irrig. Drain Eng., 2013, 139, 313-324.

18. Tiwary, P. et al., Pedotransfer functions: a tool for estimating hydraulic properties of two major soil types of India. Curr. Sci., 2014, 107, 1431-1439.

19. NBSS Publication, Soils of Karnataka. In Soils of Karnataka for Optimizing Land Use, ICAR-NBSS\&LUP, Nagpur, Maharashtra, Publ. No. 47, 1998.

20. Hegde, R., Niranjana, K. V., Srinivas, S., Danorkar, B. A. and Singh. S. K., Site-specific land resource inventory for scientific planning of Sujala watersheds in Karnataka. Curr. Sci., 2018, 115(4), 645-652.

21. ASTM, D3385-03 Standard test method for infiltration rate of soils in field using double-ring infiltrometer. In Annual Book of ASTM Standards 04.08, American Society of Testing Materials, West Conshohocken, PA, USA, 2003

22. Liaw, A. and Wiener, M., Classification and regression by randomForest. $R$ News, 2002, 2, 18-21.

23. Breiman, L., Random forests, Machine Learn, 2001; doi:10.1023/ A:1010933404324.

24. Dharumarajan, S., Bishop, T. F. A., Hegde, R. and Singh, S. K. Desertification vulnerability index - an effective approach to assess desertification processes: a case study in Anantapur District, Andhra Pradesh, India. Land Degrad. Dev., 2018, 29 150-161; https://doi.org/10.1002/ldr.2850.

25. Dharumarajan, S. et al., Biophysical and socio-economic causes for increasing fallow lands in Tamil Nadu. Soil Use Manage., 2017, 33, 487-498.

26. Adhikary, P. P. et al., Pedotransfer functions for predicting the hydraulic properties of Indian soils. Aust. J. Soil Res., 2008, 46, 476-484.

27. Mohanty, M., Sinha, N. K., Painuli, D. K., Bandyopadhyay, K. K., Hati, K. M., Reddy, K. S. and Chaudhary, R. S., Pedotransfer functions for estimating water content at field capacity and wilting point of Indian soils using particle size distribution and bulk density. J. Agric. Phys., 2014, 14(1), 1-9.

28. Dabral, P. P. and Pandey, P. K., Models to estimate soil moisture retention limits and saturated hydraulic conductivity. J. Indian Water Resour. Soc., 2016, 36(1), 50-55.

29. Shwetha, P. and Varija, K., Soil water-retention prediction from pedotransfer functions for some Indian soils. Arch. Agron. Soil Sci., 2013, 59(11), 1529-1543.

30. Mahdian, M. H., Oskoee, R. S., Kamali, K., Angoshtari, H. and Kadkhodapoor, M. A., Developing pedotransfer functions to predict infiltration rate in flood spreading stations of Iran. Res. J. Environ. Sci., 2009, 3(6), 697-704.

ACKNOWLEDGEMENTS. We thank all the University partners of Sujala III project (UAS, Bengaluru, UAS, Dharwad; UAHS, Shimoga; UAS, Raichur and UHS, Bagalkot) for providing infiltration data for this study. We also thank Karnataka Watershed Development Department and World Bank for funding the project.

Received 17 October 2018; revised accepted 7 January 2019

doi: $10.18520 / \mathrm{cs} / \mathrm{v} 116 / \mathrm{i} 7 / 1237-1246$

\section{Impact of Pusa hydrogel application on yield and productivity of rainfed wheat in North West Himalayan region}

\author{
Trisha Roy*, Suresh Kumar, Lekh Chand, \\ D. M. Kadam, Bankey Bihari, S. S. Shrimali, \\ Rajesh Bishnoi, U. K. Maurya, Madan Singh, \\ M. Muruganandam, Lakhan Singh, \\ S. K. Sharma, Rakesh Kumar and Anil Mallik \\ ICAR-Indian Institute of Soil and Water Conservation, \\ Dehradun 248 195, India
}

Farmers in the North West Himalayan region generally practise rainfed agriculture and have very limited scope for irrigation. Water scarcity is a major constraint for crop production in these areas. This problem exacerbates further during the Rabi season where vagaries of winter rain result in complete crop failure. This study was conducted in the Raipur Block of Dehradun district in the farmer's field to study the impact of hydrogel on yield and productivity of wheat. Hydrogel is a hydrophilic polymer having high water holding capacity and can provide water to crops during moisture stress. Hydrogel was applied in the field in $R a b i$ wheat with two broad treatments, i.e. with hydrogel (WH) and without hydrogel (WHO). Each treatment was replicated ten times, i.e. ten demonstrations were laid out in the field conditions. Hydrogel was applied at the rate of $5 \mathrm{~kg} \mathrm{ha}^{-1}$ and observations related to various plant growth parameters and yield were recorded. The plant population in hydrogel plots increased by $22 \%$ compared to the non-hydrogel treated plots. The effective tillers, plant height, ear length and grains per ear significantly improved due to hydrogel application. The total yield as well as grain yield increased significantly after hydrogel amendment. The improved performance of wheat upon hydrogel application was evident in the field. This technology could be promising in terms of productivity improvement of rainfed crops and in combating the moisture stress in agriculture.

Keywords: Hydrogel, Northwest Himalayas, rainfed wheat, yield.

DESPITE the fast-paced development in agricultural sector, a majority of the arable area in our country (i.e. around $67 \%$ of the net sown area) still remains under rainfed condition ${ }^{1}$. Even after achievement of full irrigation potential of the country by various Government schemes like the 'Pradhan Mantri Krishi Sinchayi Yojna' and 'Har Khet Ko Pani' about $40 \%$ of the agricultural land is still in need of irrigation. Thus, a majority of the cultivated area across the length and breadth of the country is primarily dependent on the monsoon for livelihood

*For correspondence. (e-mail: trisha17.24@gmail.com) 
security. The burgeoning population and increased food demand puts substantial pressure on these rainfed areas which lacks assured irrigation for crops and have dwindling water resources for daily house hold purposes. The present productivity of rainfed areas needs to be raised from $1 \mathrm{t} \mathrm{ha}^{-1}$ to $2 \mathrm{tha}^{-1}$ to feed the increasing population $^{1}$. This has created immense burden on natural resources leading to their over exploitation in these areas and poor quality of life. About $82 \%$ of the rural Indian population dwell in the rainfed areas of the country ${ }^{2}$ and in terms of water stress India is ranked 41st among 181 countries $^{3}$. The population under rainfed conditions is most vulnerable to the vagaries of climate change, failure of monsoon and increased variability in rainfall pattern. It adversely impacts agriculture, livestock as well as the human population of the rainfed region causing an overall marginalization of people to extreme poverty ${ }^{4}$.

The impact of water scarcity on agriculture has become more prominent under the climate change scenario, since agriculture sector consumes the maximum water $(85 \%)$ when compared to the industry $(10 \%)$ and domestic sector $(5 \%)^{3}$. Several efforts are being planned and developed to improve the water-use efficiency in agriculture. Adoption of alternate micro-irrigation methods like sprinkler, drip systems, mechanical measures of water harvesting, various management practices like reduced tillage, minimum tillage, compartmental bunding, ridge furrow methods, mulching, etc. are under practice by farmers for managing the scarce water resource. Employing chemicals like anti-transpirants and hydrogel are a few other methods, adopted to improve the water-use efficiency in agriculture systems.

Hydrogel is a synthetic polymer used is soil amendment. Hydrogel is insoluble, hydrophilic in nature and can absorb large quantity of water ${ }^{5}$. Hydrogels have great potential in areas where opportunity for irrigation is limited and can increase the water availability during crop establishment. The capacity of the hydrogel to absorb and retain water is as much as $80-180$ times its original volume ${ }^{6}$ while on weight basis it can absorb as high as 400 times its original weight ${ }^{3}$. The hydrogels can also modify various physical properties of soil like infiltration rates, density, soil structure and compaction, etc. ${ }^{7}$. Various reports have suggested the beneficial impact of hydrogel in crop growth and soil properties. Hydrogel applied at the rate of $5 \mathrm{~kg} \mathrm{ha}^{-1}$ along with farm yard manure (FYM) in an alluvial sandy loam soil significantly impacted hydrological properties of soil like the field capacity, plant available water content, relative field capacity and saturated hydraulic conductivity ${ }^{8}$. Rice is grown under waterlogged conditions and any kind of water stress has adverse effect on the rice yield. Hydrogel application in aerobic rice improved the yield and yield components of rice when grown under aerobic condition ${ }^{9}$. Grain yield, nutrient uptake and water-use efficiency improved in winter wheat when hydrogel was applied at the rate of $5 \mathrm{~kg} \mathrm{ha}^{-1}$ in a sandy loam soil ${ }^{10}$, while in a clay loam soil with the same dose of hydrogel application along with recommended dose of fertilizer $8.48 \%$ increase in yield was observed ${ }^{11}$.

The hydrogel as a conditioner has the potential to improve water-use efficiency and increase the yield of crops. Its application can reduce the number of irrigations required for the optimum crop growth without compromising the grain yield in the wheat growing regions of northwestern, central and peninsular zones of India ${ }^{12}$. Considering the sensitive micro climatic condition of North West Himalayan region in Dehradun district, hydrogel can be a boon in this region. The hill population engaged in agriculture mainly practice subsistence farming with only $15.8 \%$ of the total area linked to irrigation facilities ${ }^{13}$. Thus, water scarcity is a major problem for farmers in the mountain region. With the main focus of the Government in increasing water productivity of crops, hydrogel can be a good technology option to increase agricultural productivity in the hilly rainfed terrains. The present study evaluated the impact of hydrogel on yield and productivity in Rabi wheat on farmer's field in Raipur block of Dehradun district, Uttarakhand. In Dehradun mostly farmers practice low input subsistence agriculture under rainfed conditions. Though the average annual rainfall of the region is around $1600 \mathrm{~mm}$, the steep topography, light soil texture (generally sandy loam with $25-30 \%$ coarse fragments) and high infiltration rates reduce the moisture storage in the soil profile. Thus, water becomes the most limiting factor for crop production in this region. In Rabi season the crop growth is completely dependent on winter rains and any aberration may lead to entire crop failure. This background propelled the present study to examine the impact of hydrogel application in field condition on the yield and productivity in Rabi wheat. Since wheat is the most widely grown crop during winter by the farmers of Uttarakhand, this was deliberately chosen for the study. Hydrogel as a soil conditioner was introduced for the first time in this agro-ecological region and is a new concept among the farming community of this area.

The present study was conducted in the Raipur Block of Dehradun district, Uttarakhand in adopted villages under the Farmers FIRST project of Indian Council of Agricultural Research during November 2017. Badasi Gaon group of hamlets were selected for the present experiment. It is located between $30.25^{\circ} \mathrm{N}$ and $78.17^{\circ} \mathrm{E}$, at an elevation of $680 \mathrm{~m}$ amsl. The mean maximum annual temperature of the area is $30.2^{\circ} \mathrm{C}$ while the mean minimum annual temperature is $10^{\circ} \mathrm{C}$. The mean annual rainfall of the area is around $1600 \mathrm{~mm}$. The experiment was conducted in the farmer's field with two treatments: (a) wheat grown with hydrogel applied at the rate of $5 \mathrm{~kg} \mathrm{ha}^{-1}$ (WH), (b) wheat grown without hydrogel (WHO). For each treatment ten demonstrations were established (each demonstration was a replication). The selection of the 
farmers was completely based on their interest to use hydrogel as a soil conditioner. Observations related to yield and productivity were taken from unit area $\left(1 \mathrm{~m}^{2}\right)$ from each plot to maintain uniformity in observations. The wheat variety HS-507 was used for the present study as it is well suited for the North West Himalayan region.

Soil samples were collected from surface $(0-15 \mathrm{~cm})$ of the study area. The soil texture was sandy loam with $46.4 \%$ sand, $37.6 \%$ silt and $16.0 \%$ clay. The topography was sloping to gently sloping with slope varying from $3 \%$ to $8 \%$. The soil in the Doon valley belongs to the order Inceptisol showing not much horizonation. The $\mathrm{pH}$ of surface soil is acidic varying from 5.5 to 5.7 . The total $\mathrm{N}$ content in soil varied from $0.07 \%$ to $0.08 \%$; the available $\mathrm{P}$ content was $46 \mathrm{~kg} \mathrm{ha}^{-1}$ and the available $\mathrm{K}$ content was $155 \mathrm{~kg} \mathrm{ha}^{-1}$. The bulk density of surface layer was $1.43 \mathrm{Mg} \mathrm{m}^{-3}$ and the water holding capacity of the soil was $39.2 \%$.

Pusa hydrogel is a carboxymethyl cellulose based polymer gel manufactured by $\mathrm{M} / \mathrm{s}$ Earth Internationals under the trade name of Varidhar G1. The physical appearance of hydrogel is loose, granular, powdery formation with light yellowish colour. When the hydrogel comes in contact with atmospheric moisture it tries to form clumps losing its free flowing characteristic. Thus, necessary precautions were taken to avoid any kind of moisture contamination during hydrogel application.

The dose of hydrogel as suggested in the literature varies from 2.5 to $5 \mathrm{~kg} \mathrm{ha}^{-1}$ depending on the soil texture. A lower dose is recommended for clayey soil with higher moisture holding capacity while a higher dose is recommended for sandy soil with lower moisture holding capacity. In this study a higher dose, i.e. $5 \mathrm{~kg} \mathrm{ha}^{-1}$ was used, as the experimental soil was sandy loam in texture. Hydrogel was applied to the farmer's field by the broadcasting technique as they were normally not following line sowing procedure for crops. Hydrogel was applied in the field by mixing with dry soil in a ratio of $1: 10$ for uniform distribution in the field. After application it was mixed with soil during final land preparation for uniform mixing in the upper soil layer $(0-15 \mathrm{~cm})$.

Carboxymethyl cellulose based gel is biodegradable with a shelf life of 2-5 years in the soil ${ }^{3}$. Thus, in our study, hydrogel was applied once during Rabi season of 2017 just before the sowing of wheat during final field preparation following the same methodology as described above.

The yield and yield parameters of wheat were recorded in the present study. Plant height, number of tillers, number of effective tillers, grain yield, total yield and root length were recorded for both the treatments. The observations were recorded from $1 \mathrm{~m}^{2}$ area from the middle of the plot.

The data recorded in the farmer's field was analysed statistically. The mean of each parameter for both treated and control plots was compared statistically using $t$-test for independent sample set. For various parameters the critical difference (CD) among the treated and control plots was worked out.

Application of hydrogel in Rabi wheat significantly impacted plant population and tillering. The plant population of wheat per $\mathrm{m}^{2}$ was 210 for hydrogel applied plots while it was only 163 per $\mathrm{m}^{2}$ for the non-hydrogel applied plots $(\mathrm{CD} P<0.05=38.04)$ (Figure 1). The plant population of wheat increased significantly in hydrogel applied plots. Effective tillering in wheat was evident posthydrogel application. For WH the effective tillers per plant were 7 while for WHO plots it was only 5 (Figure 2).

The data for total effective tillering in wheat is presented in Figure 3. Maximum tillering was observed in the hydrogel applied plots with a value of $1541 \mathrm{~m}^{2}$. For the control plots the effective tillers per $\mathrm{m}^{2}$ was 850

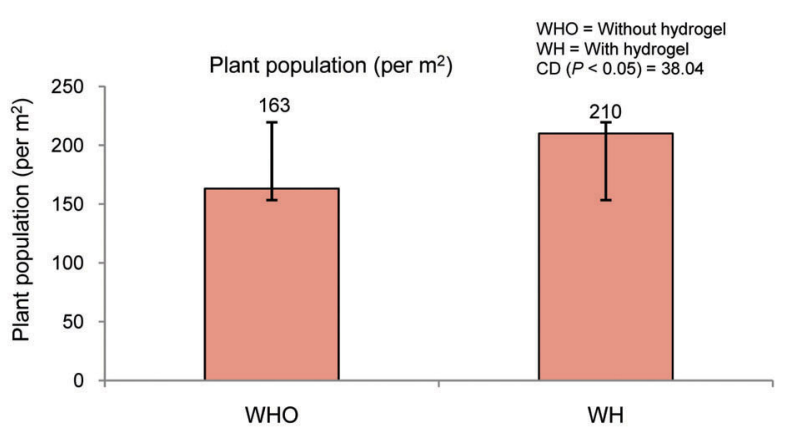

Figure 1. Plant population of wheat as affected by application of hydrogel.

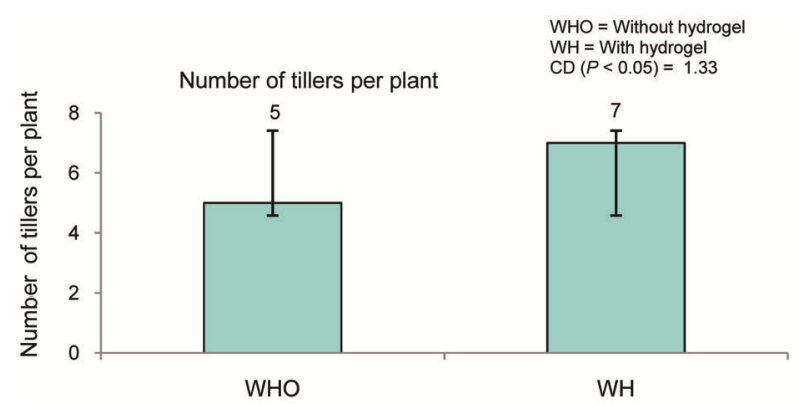

Figure 2. Impact of hydrogel on tillering of wheat.

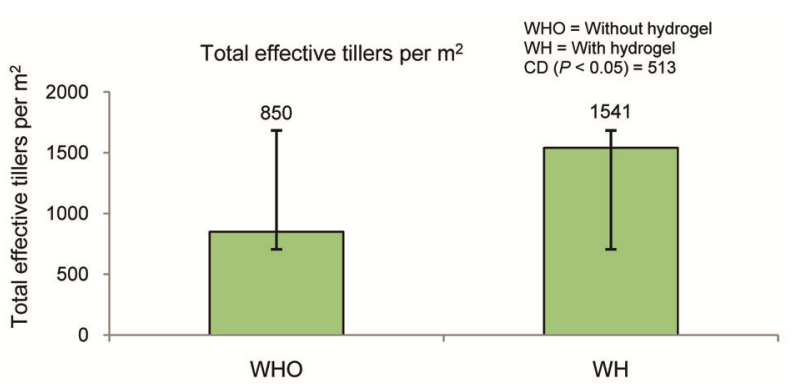

Figure 3. Total effective tillers per $\mathrm{m}^{2}$ as affected by hydrogel application. 
which was notably less than the hydrogel applied plots, indicating the positive impact of hydrogel application in tillering and consequent crop yield.

Hydrogel is hydrophilic in nature with the capacity to absorb huge quantity of water almost 200-400 times its weight $^{3}$. Thus, its application in rhizosphere helps to retain moisture for a longer time period and helps overcome dry spells. Increased moisture availability in the surface soil layer enhanced germination of wheat and resulted in increased plant population in the present study. There was an increment of $22 \%$ in plant population in $\mathrm{WH}$ plots compared to WHO. Increased plant population in turn indicates higher tillering and a higher number of effective tillers per unit area. Enhancement in the number of tillers is solely attributed to hydrogel application since all other management practices were uniformly practised by the farmers for both $\mathrm{WH}$ and WHO. Significantly higher tillering in wheat due to hydrogel application at the rate of $2.5 \mathrm{~kg} \mathrm{ha}^{-1}$ was observed ${ }^{14}$. Rice crop also showed robust tillering due to more moisture retention with hydrogel ${ }^{9}$.

The impact of hydrogel application was not significant on plant height as seen in Figure 4. The mean plant height in hydrogel applied plot was $48 \mathrm{~cm}$ which is statistically at par with mean plant height of control which was $52 \mathrm{~cm}$. Thus, though tillering was impacted directly due to application of hydrogel there was no difference in the plant height indicating that increased water availability improved the reproductive growth of the plants rather than the vegetative growth like elongation of plants.

The leaves are the main photosynthetic organs in the plant which ultimately relocates photosynthates from vegetative to reproductive parts. The number of leaves thus, can have direct implication on the crop yield. The present study revealed that the application of hydrogel had significant impact in increasing the number of leaves per plant (Figure 5). The average number of leaves per plant was 7 in WH plots while for control it was only 5 . The increased leaf number indicates the positive impact of hydrogel on wheat growth and thus, can be used in the rainfed agriculture of Uttarakhand for supporting crop growth during the Rabi season when farmers rely on winter rains.

No significant difference was observed between the control and the hydrogel applied plots in terms of root growth in wheat crop (Figure 6). The mean root length was $11 \mathrm{~cm}$ for control plots while it was $12 \mathrm{~cm}$ for hydrogel applied plots and no conclusive inference could be drawn from this data regarding the influence of hydrogel on wheat crop. In contrast to this finding, significant increment in root length of tomato due to application of hydrophilic polymer gels has been reported ${ }^{15}$. Improvement in root biomass and root length was reported in ornamental plant Parthenocissus quinquefolis due to hydrogel amendment ${ }^{16}$.

Observations were recorded for different yield parameters for wheat like spikelet population, length of spikelet and grains per spike. Statistical analysis showed significant difference between the hydrogel and non-hydrogel treated plots. The number of wheat ears per $\mathrm{m}^{2}$ displayed significant difference between hydrogel treated and non-hydrogel treated plots. When hydrogel was applied the number of wheat ears per $\mathrm{m}^{2}$ rose to 210 while in plots without hydrogel application it was only 163 (Figure 7). This is indicative of the improved water productivity due to hydrogel application which enhanced various growth parameters of wheat during the Rabi season.

The ear length of wheat also showed significant increase due to hydrogel application (Figure 8). A 28\% increase in ear length was recorded. The ear length was $11.1 \mathrm{~cm}$ for WH while it was $8 \mathrm{~cm}$ for WHO.

The hydrogel application had a positive influence on the number of grains per spike which could give an indirect estimation of the wheat yield (Figure 9). The WHO showed 45 grains per ear while WH showed 66 grains per ear. The increase in wheat grain per ear was $32.1 \%$ due to application of hydrogel. Thus, the use of hydrogel as a

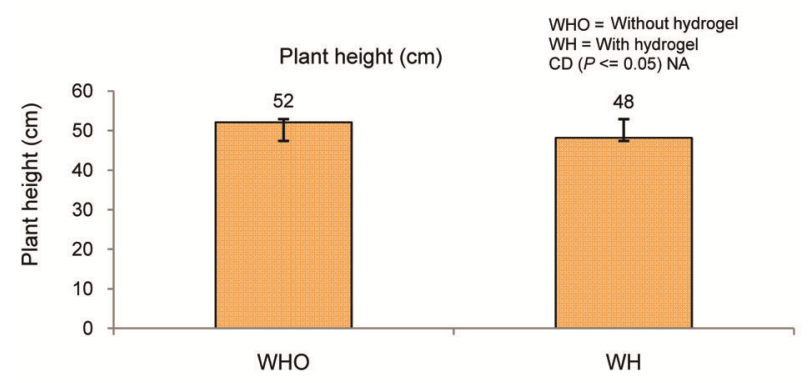

Figure 4. Variation in plant height as affected by application of hydrogel.

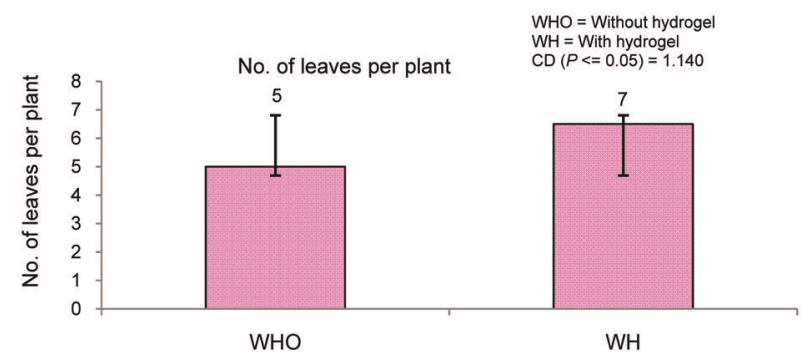

Figure 5. Number of leaves per plant as affected by the application of hydrogel.

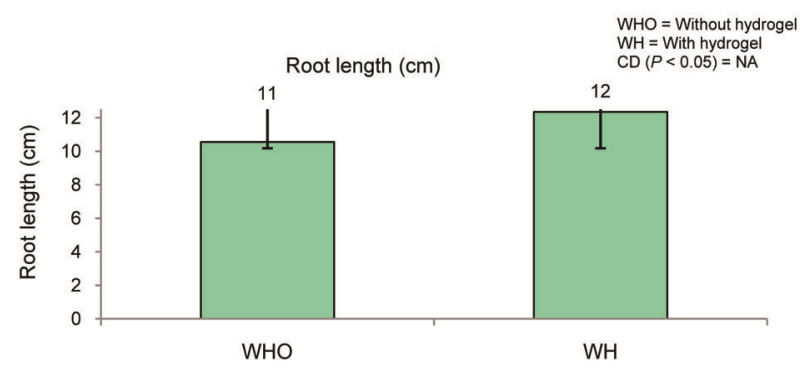

Figure 6. Root length as affected by hydrogel application. 
soil conditioner in wheat crop gave a definite advantage in the wheat yield parameters and consequently improved the productivity of wheat in the foot hill region of North Western Himalayas.

Encouraging impact of hydrogel application on yield attributes of different crops has been reported by various researchers. Chrysanthemum grown in a soil-less medium with hydrogel application $(0.5 \% \mathrm{wt} / \mathrm{wt})$ showed increased number of flowers per plant as well as flower size compared to $\mathrm{WHO}^{17}$. Increased yield in soybean, cucumber, rice, etc. due to hydrogel application has been reported by several workers ${ }^{11,18,19}$. Increased spike length and the number of grains per ear for wheat have also been reported earlier ${ }^{19}$. The number of ears formed is governed by the number of effective tillers which was increased due to hydrogel application. The plant growth is governed by various factors of which water and nutrient are the two

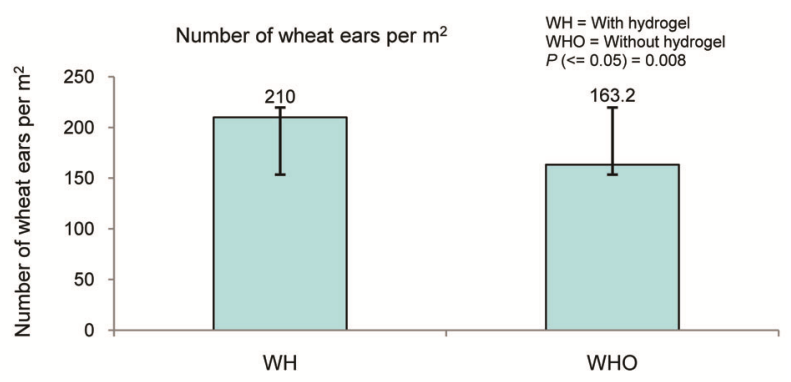

Figure 7. Number of wheat ears per $\mathrm{m}^{2}$ as affected by hydrogel application.

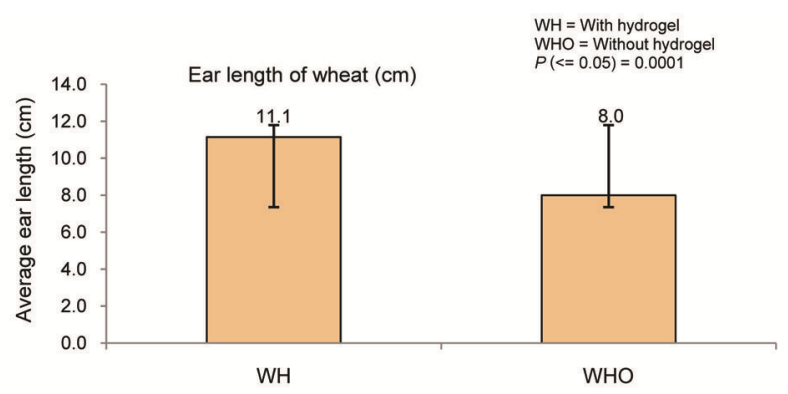

Figure 8. Spike length of wheat as affected by hydrogel application.

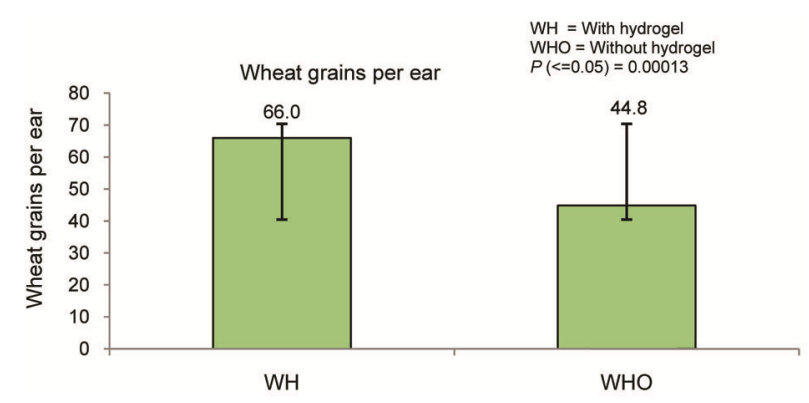

Figure 9. Number of grains per spike as affected by hydrogel application. most important components. The optimum supply of both components ensures increased cell division and hence better plant growth and higher ear length for the hydrogel amended plots. Increase in the number of grains per ear indicates better absorption of plant nutrients and higher photosynthetic activity resulting in more carbohydrate assimilation. Since hydrogel application is likely to improve the water availability to wheat, this concurrently improves the nutrient uptake and photosynthetic activity resulting in increased number of grains per ear.

The wheat yield increased 1.64 fold due to application of hydrogel. The yield per $\mathrm{m}^{2}$ was $521.5 \mathrm{~g}$ for WH plots while it was $317.5 \mathrm{~g}$ for WHO plots (Figure 10). The grain yield (Figure 11) varied between $224.4 \mathrm{~g} \mathrm{~m}^{-2}$ for WH plots whereas for WHO it was $148.3 \mathrm{~g} \mathrm{~m}^{-2}$. Significant increase in yield of crops like wheat, soybean has been observed due to application by hydrogel ${ }^{14,19}$. Hydrogel acts as a great soil conditioner and not only helps to increase the yield of wheat but also reduces the water requirement of crop by $38 \%$ to $40 \%$. Almost three to four irrigations can be saved for wheat crops under irrigated conditions while under rainfed conditions the water stress is minimized.

The grain yield is essentially a function of the number of effective tillers, number of wheat ears, number of grains per wheat ear, etc. As a result of hydrogel amendment, all these parameters were remarkably improved which was reflected in the grain yield. The grain yield increased by $51 \%$ over the control plots. The positive impact of hydrogel was clearly evident from the yield results though no soil parameters were determined.

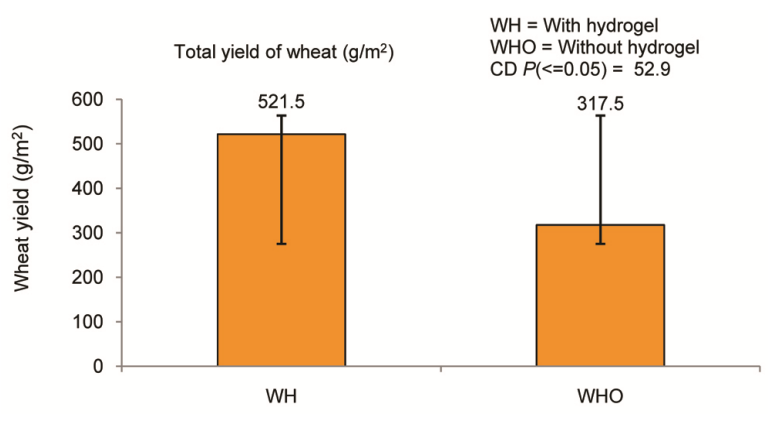

Figure 10. Impact of hydrogel application on total yield of wheat.

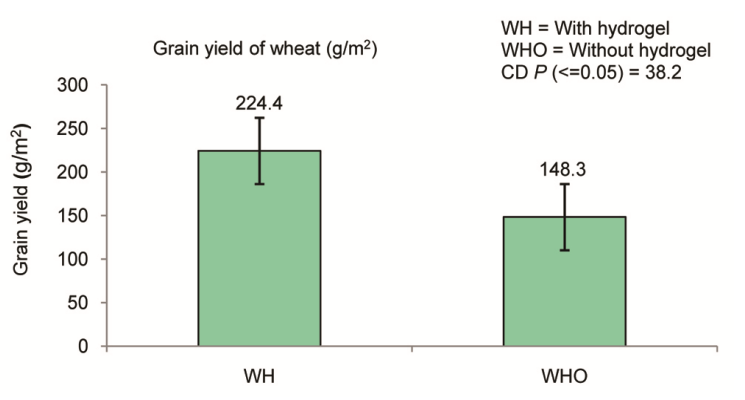

Figure 11. Impact of hydrogel application on grain yield of wheat.

CURRENT SCIENCE, VOL. 116, NO. 7, 10 APRIL 2019 


\section{RESEARCH COMMUNICATIONS}

The present study was the first attempt to introduce hydrogel in farmer's field in Raipur Block, Dehradun in the North Western Himalayan region. The results showed promising impact of hydrogel in improving the various yield parameters and the total yield of wheat in farmer's field compared to the control. Since water scarcity is one of the major problems in hill agriculture, this hydrophilic polymer gel can be a boon to farmers. The inclusion of hydrogel in rainfed agriculture will help in alleviating moisture stress of crop plants during prolonged dry period in the rainfed areas and where irrigation facilities are available this technology could reduce the number of irrigation applied to crops. Two irrigations in wheat can be saved by application of hydrogel without compromising the grain yield ${ }^{3}$. Thus, hydrogel can be a real advantage in terms of water saving during Rabi season. The current study involved first time introduction of this polymer gel in the area and was well accepted by farmers in the region as they perceived it as a radical technology which could help in solving the water woes of the farming community.

1. Venkateswarlu, B., Rainfed agriculture in India: issues in technology development and transfer. Model training course on Impact of climate change in rainfed agriculture and adaptation strategies, CRIDA, Hyderabad, India, 22-29 November 2011.

2. Fan, S. and Hazel, P., Should developing countries invest more in less-favored lands? an empirical analysis of rural India. Econ. Pol. Wkly, 2000, 34, 1455-1464.

3. Kalhapure, A., Kumar, R., Singh, V. P. and Pandey, D. S., Hydrogels: a boon for increasing agricultural productivity in waterstressed environment. Curr. Sci., 2016, 111(11), 1773-1779.

4. Devendra, C., Improvement of value supply chains in sustainable small ruminant production to consumption systems in Asia. Indian J. Anim. Sci., 2016, 86, 3-10.

5. Schacht, E. H., Polymer chemistry and hydrogel systems. J. Phys.: Conf. Ser., 2004, 3, 22-28.

6. Bowman, D. C. and Evans, R. Y., Calcium inhibition of polyacrylamide gel hydration is partially reversible by potassium. Hortic. Sci., 1991, 26(8), 1063-1065.

7. El-Hady, O. A. and Abo-Sedera, S. A., Conditioning effect of composts and acrylamide hydrogels on a sandy calcareous soil. II physico-biochemical properties of the soil. Int. J. Agric. Biol., 2006, 8(6), 876-884.

8. Narjary, B. and Aggarwal, P., Evaluation of soil physical quality under amendments and hydrogel applications in a soybean-wheat cropping system. Commun. Soil Sci. Plant Anal., 2014, 45(9), 1167-1180

9. Rehman, A., Ahmad, R. and Safdar, M., Effect of hydrogel on the performance of aerobic rice sown under different techniques. Plant Soil. Environ., 2011, 57, 321-325.

10. Tyagi, V., Singh, R. K. and Nagargade, M., Effect of hydrogel, NPK and irrigation levels on yield, nutrient uptake and water use efficiency of wheat (Triticum aestivum L.). Res. Crop, 2015, 16(4), 653-656.

11. Borivoj, S., Rak, L. and Bubenikova, I., The effect of hydroabsorbent on selected soil biological and biochemical characteristics and its possible use in revitalization. Ecologia, 2006, 25(4), $422-429$.

12. Annual Report, 2012-13, Directorate of Wheat Research, Karnal, 2013, p. 128.

13. Partap, T., Hill agriculture: challenges and opportunities. Indian J. Agric. Econ., 2011, 66(1), 33.

14. Dar, S. B. and Ram, H., Productivity of wheat (Triticum aestivum L.) in relation to hydrogel as influenced by different irrigation regimes and nutrient levels. Int. J. Chem. Stud., 2017, 5(5), 609613.

15. Akhter, J., Mahmood, K., Malik, K. A., Mardan, A., Ahmad, M. and Iqbal, M. M., Effects of hydrogel amendment on water storage of sandy loam and loam soils and seedling growth of barley, wheat and chickpea. Plant Soil. Environ., 2004, 50(10), 463-469.

16. Zhang, Z. J., Shi, L., Zhang, C. Y. and Zhang, J. Z., Response of Superabsorbent polymer under different water gradients on growth characteristics of Parthenocissus quinquefolis. Bull. Bot. Res., 2005, 25(1), 74-79.

17. Anupama, S., Singh, M. C., Kumar, B. S. and Kumar, P. A., Performance of new superabsorbent polymer on seedling and post planting growth and water use pattern of Chrysanthemum under controlled environment. Acta Hortic., 2005, 618, 215-224.

18. Yezdani, F., Allahadadi, I. and Akbari, G. A., Impact of superabsorbent polymer on yield and growth analysis of soybean (Glycine max L.) under drought stress condition. Pak. J. Biol. Sci., 2007, 10(23), 4190-4196.

19. Singh, S. P., Singh, R. K. and Kumar, S., Effect of irrigation schedule, mulching and hydrogel on wheat (Triticum aestivum L.). J. Pharmacog. Phyto., 2017, 6(5), 2659-2973.

ACKNOWLEDGEMENT. We acknowledge ICAR for providing funding through Farmer's FIRST Program. We thank Director, ICARIISWC, Dehradun for providing infrastructural facilities for carrying out the present work.

Received 7 August 2018; accepted 26 December 2018

doi: $10.18520 / \mathrm{cs} / \mathrm{v} 116 / \mathrm{i} 7 / 1246-1251$ 